\title{
Correction to: Philosophical Framework for Doing African Philosophy
}

\section{Correction to:}

Chapter 1 in: G. M. Kayange, Meaning and Truth in African

Philosophy, Philosophical Studies Series 135, https://doi.org/10.1007/978-3-030-01962-4_1

The book was inadvertently published with an incorrect spelling in the name "Gyeke", and also in the citation as "Gyeke 1992". It has now been corrected as "Gyekye", and the citation as "Gyekye 1992" on pages 4 and 13 of the book. The reference list has also been updated as follows:

Gyekye, K. 1992. Person and Community in Akan Thought. In Person and Community: Ghanaian Philosophical Studies, ed. K.W. Gyekye, 101-122. Washington, DC: CIPSH: The Council for Research in Values and Philosophy. 